\title{
New insight on the relationship between lethal electrical fields versus cardiomyocyte orientation
}

\author{
Fernanda dos Santos Costa Leomil ${ }^{1 *}$, Pedro Xavier de Oliveira ${ }^{1,2}$ \\ ${ }^{1}$ Department of Biomedical Engineering, School of Electrical and Computer Engineering, University of Campinas, Campinas, São \\ Paulo, Brazil. \\ ${ }^{2}$ Center for Biomedical Engineering, University of Campinas, Campinas, São Paulo, Brazil.
}

\begin{abstract}
Introduction: Cardiovascular diseases represent a major cause of death world-wide and one of their greatest complications is the development of cardiac arrhythmias, in which ventricular fibrillation (VF) stands out as the most severe one. The only therapy that reverses VF is defibrillation. However defibrillatory shock is capable of killing heart cells and it is known that the orientation of the cell major axis with respect to the electrical field (E) direction is a determining factor for cellular excitation and injury, which is leading to the development of new defibrillation protocols. The aim of this work is to fill the gap in information about cell lethality for intermediate cell orientation angles. Methods: Ventricular myocytes were extracted from adult male Wistar rats and the cells were plated in a chamber for perfusion and stimulation with bipolar voltage pulses to determine the stimulation threshold $\left(\mathrm{E}_{\mathrm{T}}\right)$. Then, monopolar stimulus was applied and amplitude was increased until cell lethal injury. This protocol was performed on four experimental groups: cells oriented at $0^{\circ}, 30^{\circ}, 60^{\circ}$ and $90^{\circ}$, with respect to E direction. Results: 87 cells were analyzed and an increase in amplitude of E associated with 50\% lethality (E50) was verified as the direction of E application and cell major axis orientation departed. Conclusion: Taken the same probability of lethality, our data suggest a nonlinear increase of $\mathrm{E}$ amplitude from $0^{\circ}$ to $90^{\circ}$ similar to that of $\mathrm{E}_{\mathrm{T}}$. These in-between data had not yet been shown and are important for service-based future defibrillation protocols.
\end{abstract}

Keywords Defibrillation, Cell electrical stimulation, Probability of cellular lethality.

\section{Introduction}

Despite the significant reduction of $25.3 \%$ in the mortality rate associated with cardiovascular diseases between 2004 and 2014, it remains as the leading cause of death worldwide, accounting for the death of 17.3 million people out of 54 million of all deaths in 2013 (Benjamin et al., 2017). One of the major complications resulting from cardiovascular diseases is the development of cardiac arrhythmias, in which ventricular fibrillation (VF) stands out as the most severe and life-threatening arrhythmia, being able to quickly lead to the development of cardiac arrest and even death.

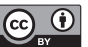

This is an Open Access article distributed under the terms of the Creative Commons Attribution License, which permits unrestricted use, distribution, and reproduction in any medium, provided the original work is properly cited.

How to cite this article: Leomil FSC, Oliveira PX. New insight on the relationship between lethal electrical fields versus cardiomyocyte orientation. Res Biomed Eng. 2018; 34(3):226-233. DOI: $10.1590 / 2446-4740.180023$.

*Corresponding author: Fernanda dos Santos Costa Leomil, Department of Biomedical Engineering, School of Electrical and Computer Engineering, State University of Campinas, Av. Albert Einstein, 400, Cidade Universitária, CEP 13083-852, Campinas, SP, Brazil. E-mail: fernandaleomil@ceb.unicamp.br

Received: 16 April 2018 / Accepted: 29 June 2018
The only available therapy capable of terminating VF is defibrillation (Weisz, 2009; Zipes et al., 2006), which consists on the application of high intensity electrical fields (HEF) in the heart. Although the electrical field intensity threshold required for heart defibrillation is $6 \mathrm{~V} / \mathrm{cm}$ (Ideker et al., 1995), this field magnitude needs to be achievable throughout the myocardium, implying that high-intensity shocks are necessary to obtain successful defibrillation. Due to the anisotropic nature of the heart tissue, non-uniform potential gradients are generated, which may expose some regions of the heart to an electrical field (E) as large as $100 \mathrm{~V} / \mathrm{cm}$ (Yabe et al., 1990). This can lead to depression of electrical and contractile cell functions and even cell death (Oliveira et al., 2008; Prado et al., 2016).

It is believed that cell injuries associated with defibrillation process are probably caused by the electroporation phenomenon: the opening of non-selective pores in the cell membrane by the application of HEF, allowing the unrestrained exchange of water and ions (Miklavcic et al., 2010; Ivorra, 2010; Jones et al., 1987; Klauke et al., 2010; Kotnik et al., 2003; Krauthamer and Jones, 1997; Nikolski and Efimov, 2005; Tsong, 1991; Weaver, 1994). When $\mathrm{E}$ is sufficiently high, it can cause cell irreversible hypercontracture, by the excessive increase of the intracellular calcium concentration, as well as the loss of its physical integrity (Goulart et al., 2012; Knisley and Grant, 1995; Oliveira et al., 2008). The electroporation 
phenomenon depends on the transmembrane potential $\left(\mathrm{V}_{\mathrm{m}}\right)$ exceeding a certain threshold (Fedorov et al., 2008; Ivorra, 2010; Kotnik et al., 2003; Prado et al., 2016) and the maximum $V_{m}$ variation depends directly on the magnitude of the applied E, cell geometry (cell width and length) and also on the E orientation with respect to the cell major axis, as described by the electromagnetic model proposed by Klee and Plonsey (Klee and Plonsey, 1976).

The response of cardiac cells to E application has been receiving much attention from the literature, from the point of view of both physiological aspects involved and for possible clinical applications. Every cell in the heart is independently excitable and capable of triggering its contractile mechanism and understanding how they individually respond to $\mathrm{E}$ may aid understanding the heart response as a whole (Bardou et al., 1990; Penna and Bassani, 2010; Tung et al., 1991).

It has already been reported that stimulus orientation influences the E excitation threshold $\left(\mathrm{E}_{\mathrm{T}}\right)$ and that there is a non-linear increase in $\mathrm{E}_{\mathrm{T}}$ for angles between $0^{\circ}$ and $90^{\circ}$, as the angle between $\mathrm{E}$ direction and cell orientation increases (Bassani et al., 2006). Thus, $\mathrm{E}_{\mathrm{T}}$ for a cell oriented at $90^{\circ}$ is about two times greater than that for another oriented at $0^{\circ}$. Studies were also performed to investigate whether E magnitude for a same probability of lethality (lethal E) would also increase if cell orientation was changed from $0^{\circ}$ to $90^{\circ}$ and, indeed, it was found that, E needed to cause lethal injury to $50 \%$ of the cells oriented at $90^{\circ}$ was twice as large for cells oriented at $0^{\circ}$ (Oliveira et al., 2008). Although the authors have obtained information regarding the angles displaying the highest $\mathrm{E}$ variation (Oliveira et al., 2008), only these two values are still a weak evidence to describe cell lethality behavior, especially because the phenomenon by which cell death is believed to occur (electroporation) is still not fully understood. Therefore, direct interpolation might be an oversimplification and novel data in this gray region would be a more reliable approach. The aim of this work is to supply data in between these angles that display the highest $\mathrm{E}$ variation in order to clarify how the increase steps in.
Considering that heart cells receiving a defibrillation shock are oriented in different directions with respect to that electric field, it is important to be aware of the values of fields that are lethal to the myocardial cells in different orientations, in order to optimize the defibrillatory protocols so they may cause the least possible lesions to the patients.

\section{Methods}

\section{Isolated rat myocytes}

Left ventricular myocytes were isolated from hearts of adult (4-6 months-old) male Wistar rats. The cardiac myocytes were isolated from 32 rats by coronary perfusion with collagenase I at $37^{\circ} \mathrm{C}$, as described by Penna and Bassani (Penna and Bassani, 2010). The experimental protocol was approved by the Institutional Committee for Ethics in Animal Research (CEUA/IB/UNICAMP, protocol 4093-1(K)).

\section{Experimental protocol}

The schematic representation of the experimental setup is shown in Figure 1. After treatment with collagen to support cell adhesion, 20 minutes were waited and then approximately $150 \mu \mathrm{l}$ of cells in solution were inserted in the perfusion chamber (Figure 1, developed by CEB/UNICAMP; Campinas, SP, Brazil) for perfusion and stimulation, whose walls were made of acrylic and the bottom was a glass coverslip. For cell stimulation, a pair of platinum electrodes were placed along the lateral inner walls, $0.75 \mathrm{~cm}$ apart, parallel to the solution flow direction, allowing a laminar flow of solution in a constant volume and an approximately constant $\mathrm{E}$ (Oliveira et al., 2008). Another 20 minutes were waited for cell adhesion onto the coverslip and the chamber was placed on an inverted microscope (developed by CEB/UNICAMP; Campinas, SP, Brazil - Figure 1) and cells were perfused $(\sim 3 \mathrm{~mL} / \mathrm{min}$ ) with Tyrode's solution (composition in $\mathrm{mM}): 140 \mathrm{NaCl}, 6 \mathrm{KCl}, 1.5 \mathrm{MgCl}_{2} \cdot 6 \mathrm{H}_{2} \mathrm{O}, 5$ HEPES, $1 \mathrm{CaCl}_{2} \cdot 2 \mathrm{H}_{2} \mathrm{O}, 11$ glucose, $\left.\mathrm{pH} 7.4\right)$ at $23^{\circ} \mathrm{C}$.

A suitable cell was searched in the perfusion chamber, i.e., a rod-shaped cell, distant at least $2 \mathrm{~mm}$ from the

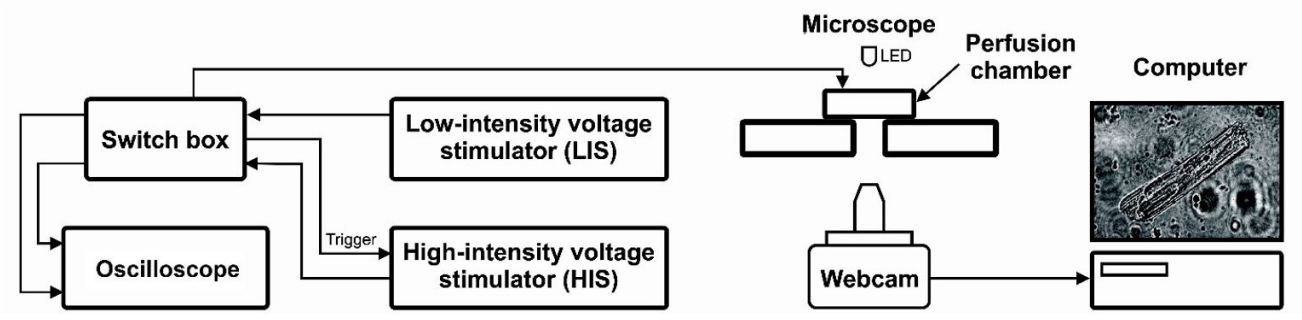

Figure 1. Schematic representation of the experimental setup. A Computer is connected to a webcam to allow visualization of the myocytes plated on the perfusion chamber. Cells could be stimulated by the LIS or by the HIS, depending on the position of the switch. Oscilloscope was used for voltage measurements during the experiment. 
electrodes (Oliveira et al., 2008), that had clear cross striations and responded to electrical stimulation by performing contractions. The experimental groups were defined as group $0^{\circ}$, group $30^{\circ}$, group $60^{\circ}$ and group $90^{\circ}$, in which the cell major axis was oriented at $0^{\circ}, 30^{\circ}$, $60^{\circ}$ or $90^{\circ}$, respectively, with respect to $\mathrm{E}$ direction. This way, in each experiment, it was obligatory that the angle between the cell and $\mathrm{E}$ direction belonged to one of the experimental groups. Measurements of cell length and width were taken with an image editing software (Adobe Photoshop). Only one cell per chamber was studied.

Alow-intensity voltage stimulator (LIS, $0-45 \mathrm{~V}$, developed by CEB/UNICAMP; Campinas, SP, Brazil - Figure 1) and a high-intensity voltage stimulator (HIS, $0-135 \mathrm{~V}$, developed by CEB/UNICAMP; Campinas, SP, Brazil - Figure 1)) were connected to a switch box (Figure 1) and its output was connected to the perfusion chamber, i.e., cells could be stimulated by LIS or HIS, depending on the switch position. An oscilloscope was used to measure the voltage output from each stimulator.

The following step consisted in determining $\mathrm{E}_{\mathrm{T}}$ for the chosen cell. LIS was used to apply $0.5 \mathrm{~Hz}$ biphasic square pulses above threshold and $10 \mathrm{~ms}$ total duration ( $5 \mathrm{~ms}$ per phase). $\mathrm{E}_{\mathrm{T}}$ was determined by decreasing the pulse intensity until the cell stopped contracting. Then the stimulation was resumed with an amplitude $20 \%$ higher than $\mathrm{E}_{\mathrm{T}}$, in order to assure that the cell would keep performing contractions in response to low intensity stimulation.

Next, the HIS, synchronized with LIS, was adjusted to produce monophasic pulses with $5 \mathrm{~ms}$ total duration. A high-intensity stimulus, with initial amplitude of $8 \mathrm{xE}_{\mathrm{T}}$ (i.e. 8 times the stimulation threshold), was applied to the cell two seconds after the last low-intensity pulse. We let the cell rest for shock recovery, usually a time of few minutes. This protocol was repeated, as can be seen in the flowchart shown in Figure 2, with an increased stimulus amplitude $\left(12 \mathrm{xE}_{\mathrm{T}}, 16 \mathrm{xE}_{\mathrm{T}}, 20 \mathrm{xE}_{\mathrm{T}}, 25 \mathrm{xE}_{\mathrm{T}}, 30 \mathrm{xE}_{\mathrm{T}}\right)$ until lethal injury was induced. Cell death was identified as the development of sustained hypercontracture accompanied by irreversible loss of responsiveness to electrical stimulation (Oliveira et al., 2008).

\section{Electrical field and maximum variation of the membrane potential estimation}

The intensity of the electrical field was calculated as in the case of a parallel plate capacitor (Gomes et al., 2001; Goulart et al., 2012) given by Equation 1:

$E=\frac{v}{d}$

where $v$ is the stimulus voltage and $d$ is the distance between the electrodes $(0.75 \mathrm{~cm})$. In order to guarantee the accuracy of the calculated electrical field, an electrical potential mapping was performed inside the perfusion chamber and showed an error $<2 \%$ for measurements made distant at least $2 \mathrm{~mm}$ from the electrodes (Oliveira et al., 2008).

The model proposed by Klee and Plonsey (Klee and Plonsey, 1976) was used to estimate the maximum variation in transmembrane electrical potential at threshold $\left(\Delta \mathrm{V}_{T}\right)$, assuming the myocyte as a prolate spheroid and that the cellular membrane has a dielectric behavior. Hence, the $\Delta \mathrm{V}_{T}$ induced by an $\mathrm{E}$ applied at an angle $\theta$ with respect to the cell major axis is given by Equation 2:

$$
\Delta V_{T}(\theta)=E\left(a^{2} A^{2} \sin ^{2} \theta+c^{2} C^{2} \cos ^{2} \theta\right)^{\frac{1}{2}}
$$

Where $a$ and $c$ are half of the cell length and width, respectively, and $A$ and $C$ are constants that depends only on the cell's geometry, as shown below:

$\epsilon=\sqrt{1-\left(\frac{a}{c}\right)^{2}}$

$A=\left\{1-\frac{1}{2 \epsilon^{3}}\left(\epsilon+\frac{1-\epsilon^{2}}{2} \ln \left(\frac{1-\epsilon}{1+\epsilon}\right)\right)\right\}^{-1}$

$C=\left\{1-\frac{1}{2 \epsilon^{3}}\left(2 \epsilon\left(\epsilon^{2}-1\right)-\left(1-\epsilon^{2}\right)+\ln \left(\frac{1-\epsilon}{1+\epsilon}\right)\right)\right\}^{-1}$

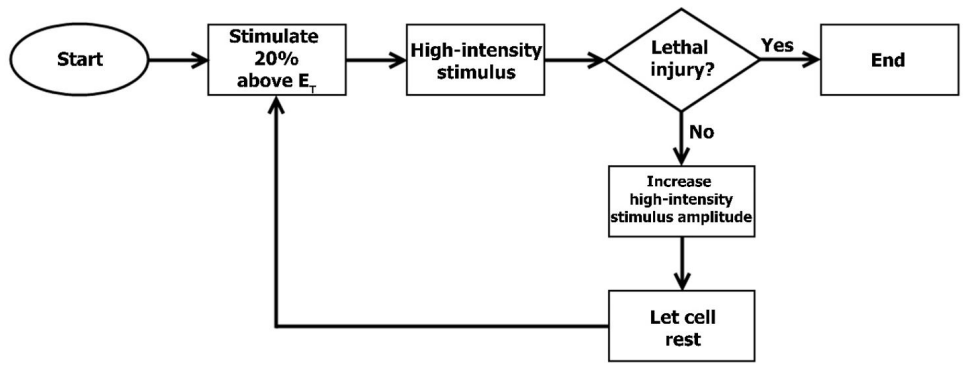

Figure 2. Flowchart representing experimental protocol adopted during experiments with cells. 


\section{Statistical analysis}

Data were analyzed with Prism 5.03 (GraphPad Software, San Diego, USA). Eighty-seven cells were used in this study, arranged in the 4 experimental groups.

The obtained data from cell length, cell width, $\mathrm{E}_{\mathrm{T}}$ and $\Delta V_{T}$ are shown as means accompanied by the standard errors of the mean. The values for each group were analyzed by three normality tests (Kolmogorov-Smirnov, D’Agostino \& Pearson e Shapiro-Wilk) and means were compared using one-way analysis of variance followed by Bonferroni's multiple comparisons test. Values of $\mathrm{p}<0.05$ were considered as indicative of statistically significant difference.

For each group, the lethal and the maximum non-lethal E were used as inputs for survival analysis fitted by a non-linear regression in order to determine the lethality curves. The data was modeled by the following function:

$$
P(E)=\frac{1}{1+\left(\frac{E 50}{E}\right)^{h}}
$$

where $P(E)$ is the probability of cell death when subjected to E, E50 is the amplitude of E related to a probability of lethality of $50 \%$ and $h$ is the Hill coefficient. The parameters calculated by fitting are shown accompanied by their $99 \%$ confidence interval (CI99), and non-overlapping intervals were considered as indicative of statistically significant difference.

\section{Results}

\section{Comparison between cell experimental groups}

Means accompanied by the standard errors of the mean of $\mathrm{E}_{\mathrm{T}}, \Delta V_{T}$, cell length and cell width can be seen in Table 1. Values of $\Delta V_{T}$, cell length and cell width were not statistically different among the experimental groups.

The only parameter that showed dependence on the angle between cell orientation and $\mathrm{E}$ direction was $\mathrm{E}_{\mathrm{T}}$ (Table 1), being statistically different in all groups, except between $0^{\circ}$ and $30^{\circ}$.

\section{Lethality}

Lethality curves for each experimental group are shown in Figure 3. E50 and $h$ means and CI99 are shown in Table 2.

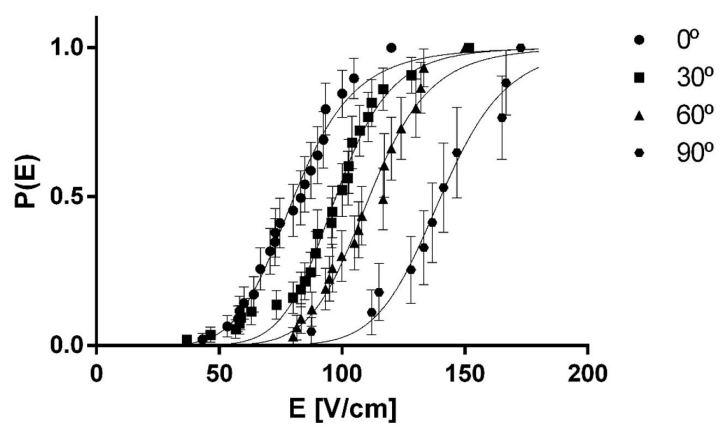

Figure 3. Curves describing the probability of lethality as a function of the applied electrical field (E) generated from non-linear fit for each studied group. Symbols represent means and vertical bars represent standard errors of the means from survival analysis.

Table 1. Cell parameters.

\begin{tabular}{cccccc}
\hline Group & $\mathbf{N}$ & $\mathbf{E}_{\mathbf{T}}[\mathbf{V} / \mathbf{c m}]$ & $\Delta \boldsymbol{V}_{\boldsymbol{T}}[\mathbf{m} \mathbf{V}]$ & Cell lenght $[\boldsymbol{\mu m}]$ & Cell Width $[\boldsymbol{\mu m}]$ \\
\hline $0^{\circ}$ & 26 & $2.87 \pm 0.11$ & $20.19 \pm 0.87$ & $134.7 \pm 3.73$ & $32.8 \pm 1.62$ \\
$30^{\circ}$ & 29 & $3.33 \pm 0.11$ & $23.00 \pm 0.75$ & $145,5 \pm 3.75$ & $37.2 \pm 1.67$ \\
$60^{\circ}$ & 21 & $4.30 \pm 0.21^{\#}$ & $21.20 \pm 1.03$ & $143.3 \pm 3.16$ & $38.7 \pm 2.05$ \\
$90^{\circ}$ & 11 & $6.34 \pm 0.24^{\#}$ & $20.77 \pm 1.11$ & $132.4 \pm 5.11$ & $35.8 \pm 2.58$ \\
\hline
\end{tabular}

Mean \pm standard error of $\mathrm{E}_{\mathrm{T}}$ (electrical field threshold), $\Delta V_{T}$ (maximum variation in transmembrane electrical potential at threshold), cell length and cell width for the experimental groups. Significant statistical difference verified with one-way analysis of variance test $(\mathrm{p}<0.0001)$ and \# indicates a significant difference from one group to all other groups (Bonferroni's test, $\mathrm{p}<0.05$ ). $\mathrm{N}$ is the number of cells in each group.

Table 2. Lethality curves fitting parameters.

\begin{tabular}{|c|c|c|c|c|}
\hline \multirow{2}{*}{ Group } & \multicolumn{2}{|c|}{ E50 } & \multicolumn{2}{|c|}{$h$} \\
\hline & Mean & CI99 & Mean & CI99 \\
\hline $0^{\circ}(\mathrm{N}=26)$ & 80.47 & $78.86-82.08^{\#}$ & 6.56 & $5.62-7.50$ \\
\hline $30^{\circ}(\mathrm{N}=29)$ & 97.48 & $95.89-99.06^{\#}$ & 8.76 & $7.32-10.19$ \\
\hline $60^{\circ}(\mathrm{N}=21)$ & 111.10 & $109.00-113.3^{\#}$ & 8.98 & $7.43-10.52$ \\
\hline $90^{\circ}(\mathrm{N}=11)$ & 140.20 & $136.00-144.4^{\#}$ & 10.56 & $6.95-14.18$ \\
\hline
\end{tabular}

Mean and 99\% confidence intervals (CI99) for electrical field intensity correspondent to probability of death equal to $50 \%$ (E50) and the respective Hill coefficient $(h)$. \# indicates that there was a statistically significant difference from one group to all other groups (through non-overlapping CI99 intervals). $\mathrm{R}^{2}>0.98$ in all cases. $\mathrm{N}$ is the number of cells in each group. 
Significant differences were noted among all groups in terms of E50, as can be seen by CI99 non-overlapping, indicating that there is dependence of the probability of lethality on the orientation of the cell in relation to the E direction. In terms of $h$, there was no significant difference among the experimental groups.

We normalized $\mathrm{E}$ by $\mathrm{E}_{\mathrm{T}}$ (Figure 4), which allowed us to verify that the normalized E50 shows statistical difference only for the $90^{\circ}$ group compared to the $0^{\circ}$ and $30^{\circ}$ groups (non-overlapping CI99s), as can be seen in Table 3. With respect to $h$, there was no statistically significant difference among any of the groups.

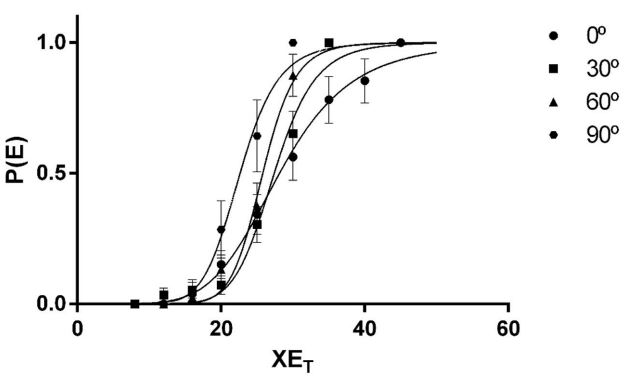

Figure 4. Curves describing the probability of lethality as a function of the applied electrical field (E). In these curves E was expressed as a multiple of the threshold electrical field $\left(\mathrm{XE}_{\mathrm{T}}\right)$. Symbols represent means and vertical bars represent standard errors of the means from survival analysis.

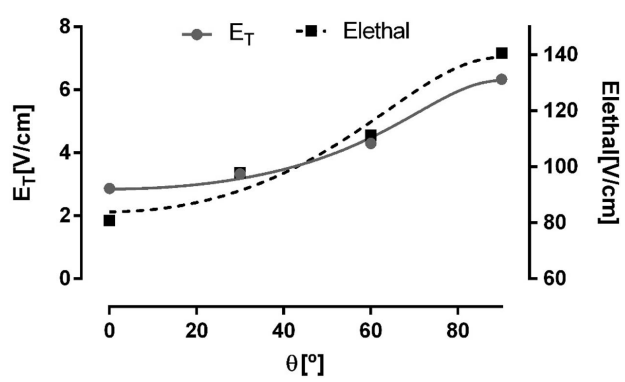

Figure 5. Plot of threshold $\mathrm{E}$ and lethal $\mathrm{E}$ mean values versus angle for four different cell orientations: $0^{\circ}, 30^{\circ}, 60^{\circ}$ and $90^{\circ}$, fitted by the Klee and Plonsey model (Klee and Plonsey, 1976).

\section{Threshold E versus lethal E}

In order to compare the way $\mathrm{E}_{\mathrm{T}}$ and lethal $\mathrm{E}$ was increasing, we plot their mean values versus angle for four different cell orientations: $0^{\circ}, 30^{\circ}, 60^{\circ}$ and $90^{\circ}$. That allowed us to verify a non-linear increase in $\mathrm{E}_{\mathrm{T}}$, which is similar to that of lethal $\mathrm{E}$

\section{Discussion}

Values found for $\Delta \mathrm{V}_{\mathrm{T}}$, cell length and cell width were similar to those previously found in the literature (Bassani et al., 2006; Goulart et al., 2012; Oliveira et al., 2008). It was not verified statistical difference among the experimental groups, which is important to ensure homogeneity of the cell samples used since it has already been shown that different cell sizes may influence $\mathrm{E}_{\mathrm{T}}$ and lethal E (Goulart et al., 2012).

On the other hand, there is a non-linear increase in $\mathrm{E}_{\mathrm{T}}$ as the angle between cell orientation and $\mathrm{E}$ direction increases (Figure 5). This is in accordance with Klee and Plonsey model (Klee and Plonsey, 1976) and with values already reported in the literature (Bassani et al., 2006; DeBruin and Krassowska, 1999; Goulart et al., 2012; Oliveira et al., 2008; Prado et al., 2016).

Regarding the lethal E, for the $0^{\circ}$ group, E50 of $80.82 \mathrm{~V} / \mathrm{cm}$ was obtained, being close to the values already reported in the literature $(\mathrm{E} 50=68 \mathrm{~V} / \mathrm{cm}$ (Tung, 1996); $\mathrm{E} 50=90.73 \mathrm{~V} / \mathrm{cm}$ (Neunlist and Tung, 1997)). Similarly, the value of E50 for the $90^{\circ}$ group $(140.7 \mathrm{~V} / \mathrm{cm})$ is also close to what have been reported so far $(\mathrm{E} 50=136.6 \mathrm{~V} / \mathrm{cm}$ (Tung, 1996)). The approximately 2 -fold ratio between $\mathrm{E} 50$ of $90^{\circ}$ oriented cells was again observed when compared to cells that were oriented at $0^{\circ}$.

The present study shows that there is a non-linear increase in $\mathrm{E}$ associated with cell lethal injury as the angle between cell orientation and $\mathrm{E}$ direction is increased, for angles between $0^{\circ}$ and $90^{\circ}$, similar to that observed for $\mathrm{E}_{\mathrm{T}}$. Thus, as can be seen in Figure 3, given the same probability of lethality, cells oriented at $0^{\circ}$ with respect to $\mathrm{E}$ have greater sensitivity to $\mathrm{E}$ than those oriented at $30^{\circ}$. Likewise, cells at $30^{\circ}$ are more sensitive to $\mathrm{E}$ when compared to those oriented at $60^{\circ}$. Finally, we

Table 3. Lethality curves fitting parameters for E expressed as a multiple of $\mathrm{E}_{T}$.

\begin{tabular}{|c|c|c|c|c|}
\hline \multirow{2}{*}{ Group } & \multicolumn{2}{|c|}{$\mathbf{E 5 0}\left[\mathbf{x E}_{T}\right]$} & \multicolumn{2}{|c|}{$h$} \\
\hline & Mean & CI99 & Mean & CI99 \\
\hline $0^{\circ}(\mathrm{N}=26)$ & 28.15 & $26.83-29.46$ & 5.62 & $4.30-6.39$ \\
\hline $30^{\circ}(\mathrm{N}=29)$ & 27.41 & $25.70-29.12$ & 9.58 & $4.41-14.48$ \\
\hline $60^{\circ}(\mathrm{N}=21)$ & 25.81 & $24.36-27.25$ & 11.42 & $4.53-18.32$ \\
\hline $90^{\circ}(\mathrm{N}=11)$ & 22.65 & $20.50-24.80^{\# *}$ & 8.52 & $2.73-14.31$ \\
\hline
\end{tabular}

Mean and 99\% confidence intervals (CI99) for electrical field intensity correspondent to probability of lethality equal to $50 \%$ expressed as a multiple of $\mathrm{E}_{T}\left(\mathrm{E} 50\left[\mathrm{xE}_{T}\right]\right)$ and the respective Hill coefficient $(h) . \mathrm{N}$ is the number of cells in each group; \#indicates that there was a statistically significant difference from this group to the $0^{\circ}$ group and $*$ indicates that there was a statistically significant difference from this group to the $30^{\circ}$ group (through non-overlapping CI99 intervals). 
verified that cells oriented at $90^{\circ}$ were the least sensitive to $\mathrm{E}$ (the $\mathrm{E}$ necessary to cause a lethal effect is greater) (Oliveira et al., 2008). This is to our knowledge the first time that lethality probability curves and lethal $\mathrm{E}$ values for cells oriented at $30^{\circ}$ and $60^{\circ}$ have been reported.

The results previously shown can be justified by assuming that the most likely phenomenon responsible for cell death is electroporation (Weaver, 1994). Electroporation manifestation depends on $\mathrm{V}_{\mathrm{m}}$ exceeding a certain threshold value and the maximum variation of this potential, $\Delta \mathrm{V}_{\mathrm{m}}$, depends on the intensity of the applied E, the cell geometry (width and length) and the angle between the cell orientation and $\mathrm{E}$ direction. Thus, assuming that the membrane is a perfect dielectric, a possible explanation for the non-linear increase observed for E50 values for cell orientations between $0^{\circ}$ and $90^{\circ} \mathrm{can}$ be obtained by calculating the $\Delta \mathrm{V}_{\mathrm{m}}$ induced by fixed $\mathrm{E}$ in a cell with average dimensions (length equal to $130 \mu \mathrm{m}$ and width equal to $30 \mu \mathrm{m}$ ) in different orientations. The effect in a cell oriented at $30^{\circ}$ is a $\Delta \mathrm{V}_{\mathrm{m}}$ equivalent to $89 \%$ of that caused to a cell oriented at $0^{\circ}$ (Klee and Plonsey, 1976). For the $60^{\circ}$ oriented cell, the $\Delta \mathrm{V}_{\mathrm{m}}$ caused is equivalent to $63 \%$ of that at $0^{\circ} . \Delta \mathrm{V}_{\mathrm{m}}$ is even smaller if the cell is oriented at $90^{\circ}$ with respect to the $\mathrm{E}$, being approximately $45 \%$. Therefore, it can be seen that as we increase the angle between the cell major axis and the direction of the applied $\mathrm{E}, \Delta \mathrm{V}_{\mathrm{m}}$ for a same $\mathrm{E}$ magnitude decreases, which would reduce the probability of pore and, consequently, the likelihood of lethality. However, because the membrane is not a perfect dielectric, these percentage values found above are not totally accurate, being overestimated, since the model proposed by Klee \& Plonsey (Klee and Plonsey, 1976) does not take into account pores opening in the membrane. Nonetheless, the model is useful to qualitatively verify the need for an increase in the external $\mathrm{E}$ as cell orientation with respect to the $E$ is increased to reach a given variation in transmembrane potential capable of causing electroporation (and consequently cell lethal injury).

From Figure 5, we can draw a similarity, although in different magnitudes, in the behavior of E50 and $\mathrm{E}_{\mathrm{T}}$ as $\theta$ increases. And although the processes of cellular excitability and electroporation of the cell membrane are considered different phenomena - since the former is a self-stimulatory process, where the opening of a certain amount of ion selective voltage-dependent channels increases membrane depolarization and, consequently, increases the probability for more channels opening, leading to the firing of action potentials, and the latter is a self-limiting phenomenon, as the ion fluxes that flow through the pores curtail membrane polarization due to the electrical field (Cheek and Fast, 2004; Neunlist and Tung, 1997) - when we expressed values of lethal $\mathrm{E}$ as multiples of $\mathrm{E}_{\mathrm{T}}$ (Table 3), we verified that the direction-dependent difference of E50 was greatly diminished (showing that $\mathrm{E}_{\mathrm{T}}$ might be a reasonable predictor of lethal E-values). Furthermore, Figure 4 displays an inverted relation: the $\mathrm{E} / \mathrm{E}_{\mathrm{T}}$ ratio for $50 \%$ lethality was $20 \%$ lower for cells oriented at $90^{\circ}$ than for cells at $0^{\circ}$. A possible explanation for this is due to the fact that, for cells oriented at $90^{\circ}$, the area of the membrane exposed to the maximum $\Delta \mathrm{V}_{m}$ is 2.5 -fold larger when compared to cells oriented at $0^{\circ}$, which implies that a larger membrane area reaches supracritical $\mathrm{V}_{\mathrm{m}}$ values and undergoes permeabilization (Oliveira et al., 2008). This type of analysis allowed us to infer that an E of about 26 times the threshold corresponds to a probability of lethality of at least $50 \%$ of the cells, regardless of their orientation.

A significant limitation to be considered in this study was the progressive increase of the HEF intensity applied during the experimental protocol, since it was a function of $\mathrm{E}_{\mathrm{T}}$. This is done with a cell carrying several shocks before dying, which activates cell repair mechanisms, reducing cell vulnerability to subsequent shocks (Spaeth et al., 2010; Steinhardt et al., 1994; Togo et al., 1999). It was observed during the experiments that damage was caused to cells, promoting reductions in cell length and reversible hypercontracture. It has already been shown that a reduction in cell length increases E50 (Goulart et al., 2012). Thus, the cumulative effect of shocks should not be overlooked and values found for lethal $\mathrm{E}$ (and cell probability of lethality) may be overestimated.

Also, we should emphasize that experiments were performed with isolated cells that were oriented at $0^{\circ}, 30^{\circ}, 60^{\circ}$ or $90^{\circ}$ with respect to the E direction. It is very difficult to directly extrapolate the results found in this work for clinical applications, since the heart has several cells of different sizes, oriented in the most diverse directions and connected through gap-junctions, in a way that each cell responds quite differently to the applied external E. It has already been shown that in heart tissue this difference in $\mathrm{E}$ response depends not only on the orientation of the cell with respect to $\mathrm{E}$ and cellular geometry, but also on the fact that the cardiac tissue is heterogeneous, resulting in the formation of virtual electrodes that modify $\mathrm{E}$ amplitudes and directions (Coster and Zimmermann, 1975; Knisley et al., 1994; Roth, 1995), while the results shown in this work were obtained in a controlled and homogenous environment.

From the present results, it is possible to conclude that cell orientation with respect to E direction directly influences the probability of lethality of isolated myocytes in response to the application of HEF and that this probability of lethality, given a same $\mathrm{E}$, is greater when $\mathrm{E}$ is applied at $0^{\circ}$ with the cell orientation and decreases non-linearly as $\mathrm{E}$ is applied closer to the $90^{\circ}$. 
These results are in line with what was theoretically predicted by the Klee and Plonsey model (Klee and Plonsey, 1976).

Our work was able to provide information about the behavior of cell lethality as a function of $\mathrm{E}$ direction and cell orientation, not only by showing that there is an increase in the probability of cell lethality, but also how this increase is happening. Results showing how cell lethality is affected by HEF for directions other than $0^{\circ}$ and $90^{\circ}$ were absent in the literature and could contribute for the design of new defibrillation protocols (Viana et al., 2016), by providing data on an E upper limit for cell survival, and also support further works in areas related to electropermeabilization and cell/tissue stimulation. Furthermore, these data could be used as adjusting or comparing parameters for computational models and simulations.

\section{Acknowledgements}

The authors are grateful to the team of R\&D staff at CEB/UNICAMP for the technical support and also to Dr. Jair Goulart and MSc. Marcelo Zoccoler for scientific support during the development of this work. This study was supported by CAPES (Coordination of Improvement of Higher Education Personnel, scholarship to FSCL).

\section{References}

Bardou AL, Chesnais JM, Birkui PJ, Govaere MC, Auger PM, Von Euw D, Degonde J. Directional variability of stimulation threshold measurements in isolated guinea pig cardiomyocytes: Relationship with orthogonal sequential defibrillating pulses. Pacing Clin Electrophysiol. 1990; 13(12 Pt 1):1590-5. http:// dx.doi.org/10.1111/j.1540-8159.1990.tb06859.x. PMid:1704510.

Bassani RA, Lima KA, Gomes PAP, Oliveira PX, Bassani JWM. Combining stimulus direction and waveform for optimization of threshold stimulation of isolated ventricular myocytes. Physiol Meas. 2006; 27(9):851-63. http://dx.doi. org/10.1088/0967-3334/27/9/008. PMid:16868351.

Benjamin EJ, Blaha MJ, Chiuve SE, Cushman M, Das SR, Deo R, de Ferranti SD, Floyd J, Fornage M, Gillespie C, Isasi CR, Jiménez MC, Jordan LC, Judd SE, Lackland D, Lichtman JH, Lisabeth L, Liu S, Longenecker CT, Mackey RH, Matsushita K, Mozaffarian D, Mussolino ME, Nasir K, Neumar RW, Palaniappan L, Pandey DK, Thiagarajan RR, Reeves MJ, Ritchey M, Rodriguez CJ, Roth GA, Rosamond WD, Sasson C, Towfighi A, Tsao CW, Turner MB, Virani SS, Voeks JH, Willey JZ, Wilkins JT, Wu JH, Alger HM, Wong SS, Muntner P. Heart disease and stroke statistics-2017 update: a report from the American Heart Association. Circulation. 2017; 135(10):e146603. http://dx.doi.org/10.1161/CIR.0000000000000485. PMid:28122885.

Cheek ER, Fast VG. Nonlinear changes of transmembrane potential during electrical shocks: role of membrane electroporation. Circ Res. 2004; 94(2):208-14. http://dx.doi.org/10.1161/01. RES.0000111526.69133.DE. PMid:14670844.
Coster HG, Zimmermann U. The mechanism of electrical breakdown in the membranes ofValonia utricularis. J Membr Biol. 1975; 22(1):73-90. http://dx.doi.org/10.1007/BF01868164. PMid:1127686.

DeBruin KA, Krassowska W. Modeling Electroporation in a Single Cell. I. Effects of field strength and rest potential. Biophys J. 1999; 77(3):1213-24. http://dx.doi.org/10.1016/ S0006-3495(99)76973-0. PMid:10465736.

Fedorov VV, Nikolski VP, Efimov IR. Effect of electroporation on cardiac electrophysiology. USA: Humana Press; 2008, p. 433-48. https://doi.org/10.1007/978-1-59745-194-9_34.

Gomes PAP, Bassani RA, Bassani JWM. Electric field stimulation of cardiac myocytes during postnatal development. IEEE Trans Biomed Eng. 2001; 48(6):630-6. http://dx.doi. org/10.1109/10.923781. PMid:11396593.

Goulart JT, de Oliveira PX, Bassani JWM, Bassani RA. The influence of cell dimensions on the vulnerability of ventricular myocytes to lethal injury by high-intensity electrical fields. Rev Bras Eng Bioméd. 2012; 28(4):337-45. http://dx.doi. org/10.4322/rbeb.2012.040.

Ideker RE, Zhou X, Knisley SB. Correlation among fibrillation, defibrillation, and cardiac pacing. Pacing Clin Electrophysiol. 1995; 18(3 Pt 2):512-25. http://dx.doi.org/10.1111/j.1540-8159.1995. tb02562.x. PMid:7777416.

Ivorra A. Tissue electroporation as a bioelectric phenomenon: Basic concepts. Berlin: Springer; 2010, p. 23-61. https://doi. org/10.1007/978-3-642-05420-4_2.

Jones JL, Jones RE, Balasky G. Microlesion formation in myocardial cells by high-intensity electric field stimulation. Am J Physiol. 1987; 253(2 Pt 2):H480-6. PMid:2441612.

Klauke N, Smith G, Cooper JM. Regional electroporation of single cardiac myocytes in a focused electric field. Anal Chem. 2010; 82(2):585-92. http://dx.doi.org/10.1021/ac901886j. PMid:20020746.

Klee M, Plonsey R. Stimulation of spheroidal cells - The role of cell shape. IEEE Trans Biomed Eng. 1976; BME-23(4):347-54. http://dx.doi.org/10.1109/TBME.1976.324597. PMid:1278928.

Knisley SB, Grant AO. Asymmetrical electrically induced injury of rabbit ventricular myocytes. J Mol Cell Cardiol. 1995; 27(5):1111-22. http://dx.doi.org/10.1016/0022-2828(95)900470. PMid:7473769.

Knisley SB, Hill BC, Ideker RE. Virtual electrode effects in myocardial fibers. Biophys J. 1994; 66(3 Pt 1):719-28. http:// dx.doi.org/10.1016/S0006-3495(94)80846-X. PMid:8011903.

Kotnik T, Pucihar G, Reberšek M, Miklavčič D, Mir LM. Role of pulse shape in cell membrane electropermeabilization. Biochim Biophys Acta - Biomembr. 2003; 1614(2):193-200. http://dx.doi.org/10.1016/S0005-2736(03)00173-1.

Krauthamer V, Jones JL. Calcium dynamics in cultured heart cells exposed to defibrillator-type electric shocks. Life Sci. 1997; 60(2):1977-85. http://dx.doi.org/10.1016/S00243205(97)00162-8.

Miklavcic D, Pucihar G, Macek Lebar A, Krmelj J, Towhidi L. The pulse intensity-duration dependency for cell membrane electroporation. In: Pakhomov AG, Miklavicic D, Markov MS, editors. Advanced electroporation techniques in biology and 
medicine. Boca Raton: CRC Press, 2010. p. 246-59. https:// doi.org/10.1201/EBK1439819067-17.

Neunlist M, Tung L. Dose-dependent reduction of cardiac transmembrane potential by high-intensity electrical shocks. Am J Physiol Circ Physiol. 1997; 273(6 Pt 2):H2817-25. http:// dx.doi.org/10.1152/ajpheart.1997.273.6.H2817. PMid:9435619.

Nikolski V, Efimov I. Electroporation of the heart. Europace. 2005; 7:S146-54. http://dx.doi.org/10.1016/j.eupc.2005.04.011.

Oliveira PX, Bassani RA, Bassani JWM. Lethal effect of electric fields on isolated ventricular myocytes. IEEE Trans Biomed Eng. 2008; 55(11):2635-42. http://dx.doi.org/10.1109/ TBME.2008.2001135. PMid:18990634.

Penna LB, Bassani RA. Increased spontaneous activity and reduced inotropic response to catecholamines in ventricular myocytes from footshock-stressed rats. Stress. 2010; 13(1):73-82. http://dx.doi.org/10.3109/10253890902951778. PMid:19697264.

Prado LN, Goulart JT, Zoccoler M, Oliveira PX. Ventricular myocyte injury by high-intensity electric field: Effect of pulse duration. Gen Physiol Biophys. 2016; 35(2):121-30. http:// dx.doi.org/10.4149/gpb_2015047. PMid:26830130.

Roth BJ. A mathematical model of make and break electrical stimulation of cardiac tissue by a unipolar anode or cathode. IEEE Trans Biomed Eng. 1995; 42(12):1174-84. http://dx.doi. org/10.1109/10.476124. PMid:8550059.

Spaeth CS, Boydston EA, Figard LR, Zuzek A, Bittner GD. A model for sealing plasmalemmal damage in neurons and other eukaryotic cells. J Neurosci. 2010; 30(47):15790-800. http:// dx.doi.org/10.1523/JNEUROSCI.4155-10.2010. PMid:21106818.

Steinhardt RA, Bi G, Alderton JM. Cell membrane resealing by a vesicular mechanism similar to neurotransmitter release. Science. 1994; 263(5145):390-3. http://dx.doi.org/10.1126/ science.7904084. PMid:7904084.

Togo T, Alderton JM, Bi GQ, Steinhardt RA. The mechanism of facilitated cell membrane resealing. J Cell Sci. 1999; 112(Pt 5):719-31. PMid:9973606.

Tsong TY. Electroporation of cell membranes. Biophys J. 1991; 60(2):297-306. http://dx.doi.org/10.1016/S0006-3495(91)820549. PMid:1912274.
Tung L, Sliz N, Mulligan MR. Influence of electrical axis of stimulation on excitation of cardiac muscle cells. Circ Res. 1991; 69(3):722-30. http://dx.doi.org/10.1161/01.RES.69.3.722. PMid: 1873867.

Tung L. Detrimental effects of electrical fields on cardiac muscle. Proc IEEE. 1996; 84(3):366-78. http://dx.doi. org/10.1109/5.486740.

Viana MA, Bassani RA, Petrucci O, Marques DA, Bassani JWM, Viana MA, Bassani RA, Petrucci O, Marques DA, Bassani JWM. System for open-chest, multidirectional electrical defibrillation. Res Biomed Eng. 2016; 32(1):74-84. http:// dx.doi.org/10.1590/2446-4740.02015.

Weaver JC. Molecular basis for cell membrane electroporationa. Ann N Y Acad Sci. 1994; 720(1):141-52. http://dx.doi. org/10.1111/j.1749-6632.1994.tb30442.x. PMid:8010633.

Weisz MT. Physical principles of defibrillators. Anaesth Intensive Care Med. 2009; 10(8):367-9. http://dx.doi.org/10.1016/j. mpaic.2009.05.002.

Yabe S, Smith WM, Daubert JP, Wolf PD, Rollins DL, Ideker RE. Conduction disturbances caused by high current density electric fields. Circ Res. 1990; 66(5):1190-203. PMID:2335021.

Zipes DP, Camm AJ, Borggrefe M, Buxton AE, Chaitman B, Fromer M, Gregoratos G, Klein G, Moss AJ, Myerburg RJ, Priori SG, Quinones MA, Roden DM, Silka MJ, Tracy C, Smith SC Jr, Jacobs AK, Adams CD, Antman EM, Anderson JL, Hunt SA, Halperin JL, Nishimura R, Ornato JP, Page RL, Riegel B, Priori SG, Blanc JJ, Budaj A, Camm AJ, Dean V, Deckers JW, Despres C, Dickstein K, Lekakis J, McGregor K, Metra M, Morais J, Osterspey A, Tamargo JL, Zamorano JL. ACC/ AHA/ESC 2006 guidelines for management of patients with ventricular arrhythmias and the prevention of sudden cardiac death: a report of the American College of Cardiology/American Heart Association Task Force and the European Society of Cardiology Committee for Practice Guidelines (Writing Committee to Develop Guidelines for Management of Patients With Ventricular Arrhythmias and the Prevention of Sudden Cardiac Death). J Am Coll Cardiol. 2006; 48(5):e247-346. http://dx.doi.org/10.1016/j.jacc.2006.07.010. PMid:16949478. 